https://doi.org/10.48009/1_iis_2005_35-42

\title{
TEACHING INFORMATION SYSTEMS ETHICS THROUGH SERVICE-LEARNING
}

\author{
Thomas S. E. Hilton, MIS, University of Wisconsin-Eau Claire, hiltonts@uwec.edu \\ Donald D. Mowry, Sociology, University of Wisconsin-Eau Claire, dmowry@uwec.edu
}

\begin{abstract}
MIS ethics education has two parts: 1) teaching the rules and 2) evoking ethical behavior. Such behavior acquisition is arguably the more difficult of the two. Skinner's behavioral reinforcement and Bandura's social learning can both strongly influence behavior acquisition, so they are incorporated into an MIS senior capstone course. MIS majors at UW-Eau Claire work in supervised teams to develop information systems for non-profit clients in the community. Clients model ethical behavior and raise ethics issues, and student efforts are publicly recognized by campus and community leaders. In the face of their obvious impact on community life and the tremendous gratitude of clients, students awaken from a state of anomie to a sense of involvement with the community that evokes ethical behavior. They experience the positive influence they can have when conducting themselves appropriately. Indications are that this experience facilitates student commitment to ethical behavior.
\end{abstract}

Keywords: information systems ethics, business ethics, computer ethics, cyber ethics, MIS, management information systems, IT, information technology, education

\section{INTRODUCTION}

Ethical behavior among information systems (IS) professionals has long been a crucial topic of higher education [23, 33, 41]. Presently it appears particularly important for several reasons. High-profile ethics breaches among influential business leaders have shown yet again both the need for ethical behavior and the sad fact that some people choose to behave unethically [9]. Additionally, increasing IS responsibility for reporting adherence to policies and regulations such as the Health Information Portability and Accountability Act and the Sarbanes-Oxley Act has made more importance IS ethics as well as establishing civil and criminal penalties for behavior that had previously been merely frowned upon [32]. Finally, increasing emphasis by accrediting bodies such as the Association to Advance Collegiate Schools of Business (AACSB) [7, 36] and the Accreditation Board for Engineering and Technology (ABET) [1] has raised the profile of collegiate IS ethics education.

\section{TWO-PART IS ETHICS EDUCATION}

MIS ethics education is often regarded as consisting of content transmission, teaching the rules as it were. However, the indisputably more important and arguably more difficult objective of MIS ethics instruction is to evoke commitment to career-long ethical behavior among the students [15].

\section{Content Transmission}

Much research surrounds the development of IS ethics content. Four foundation theories of ethics are commonly referenced: Kant's duty [20], Mill's utilitarianism [30], Rawls' justice/fairness/rights [38], and Aristotle's virtue (more recently by MacIntyre) [27]. From this foundation, more specific bodies of business ethics [40] are developed, and then principles of ethical behavior among IS users and developers are explicated [2, 4, 19]. Other topics often 
addressed are variation in IS ethics norms across cultures [14], and ways to actively participate in developing and maintaining ethics guidelines [21, 17].

In line with content development, much research surrounds the transmission of MIS ethics education. For example, much has been written about teaching a stand-alone MIS ethics course, integrating ethics content throughout the MIS curriculum, or doing some combination of the two [18]. Mechanisms for communicating the content in memorable ways have also received a generous share of attention [31], as have methods of assessing content retention among students [13].

\section{Behavior Acquisition}

Rule-learning is worthless without rule-using, but theory and practice [22] both indicate that knowing standards of ethical behavior by no means guarantees adherence to them. There is evidence this is true for college students as well as the general population. The documented prevalence of illegal file-sharing among university students [34], presumably including MIS students, is one indication that student behavior doesn't always jibe with the rules. Another indication of this is the prevalence among university students (particularly business students if Pino \& Smith [37] are to be believed) of more ordinary academic dishonesty. Add research findings on the prevalence of software piracy among college students [16] and anecdotal conversations with our own students, and a significant gap emerges between what students understand as ethical computing on the one hand and how they behave on the other.

Current MIS ethics pedagogy vis-à-vis behavior acquisition. While a gap between what we know and how we act is general to the human race, still the goal of MIS ethics instruction must be to narrow that gap as much as possible [28]. Various means of inculcating into MIS students an inclination to behave ethically have been advanced. Some typical techniques used in this effort to persuade are in-class discussion of IS ethics cases [24], personal reflection essays [6], penalties for academic dishonesty [37], and testimonials from guest speakers [26]. Yet research findings show mixed results from these efforts, at least partly because many college students apparently operate in a state of "anomie," the largely subliminal and hence unexamined assumption that they are not really members of society, that society offers no place for them or that they do not want the place it does offer [8].

Another approach to behavior acquisition. Review of psychological literature reveals a well developed body of research on methods of effecting behavior acquisition. Many historically common methods of effectively persuading people to adopt a desired behavior are no longer regarded as ethical (see Peters [35] if you don't mind nightmares), but two approaches appear both socially acceptable and remarkably effective: behavioral reinforcement [39] and social learning [5]. Behaviorism indicates that repeatedly rewarding a behavior strongly influences reward recipients to adopt the behavior. Social learning theory indicates that repeatedly observing a "credible model" (i.e., a respected and trusted person) rewarded for engaging in a behavior strongly influences observers to adopt the behavior. Thus, it appears that either personal or vicarious reinforcement could be used to instill ethical behavior in MIS students.

Is such manipulation ethical? The astute reader will note that the line between education and indoctrination begins to blur at this point in the discussion. Educators accustomed to teaching truth (or its closest available approximation) may regard the reinforcement described above as mere operant conditioning fit only for lab rats. We admit to similar misgivings that this line of reasoning risks reducing instruction to propaganda; the potential for abuse is significant [12]. However, we also find that such reinforcement occurs almost continuously both in and out of class on virtually every conceivable topic [10]. We also note innumerable precedents in current public education dating from John Dewey [11]. Thus, we assert that the concept of an instructor using behaviorist or social learning techniques to persuade MIS students to behave ethically is not unethical, per se. 


\section{CASE STUDY: A SENIOR CAPSTONE COURSE}

The above rationale persuaded us to the opinion that, once MIS ethics rules have been taught, a major remaining impediment to following them is student anomie. Moreover, we predicted that decreased student anomie would correlate with increased ethical student behavior. Finally, we hypothesized that a) engaging students in ethically significant service directly to the visible community and b) providing reinforcement for their service would result in decreased anomie and increased motivation to obey the rules of MIS ethics. We chose to measure the level of anomie and ethics motivation by interviewing the students periodically.

Community service-learning requirement. These concepts were implemented in our capstone course for MIS seniors. To satisfy a university graduation requirement that students engage in at least 30 clock-hours of approved service to the community, 103 -student teams each conducted a complete information system development project for a community client that otherwise would not be able to afford needed information infrastructure. Some clients were the Epilepsy Foundation, the National Alliance for the Mentally Ill, the YMCA, and the United Way.

Projects. A variety of projects were completed. Some of these were IT strategic planning, network development, hardware/software acquisition and deployment, web site development, client database development, system security audit/upgrade, and end-user training. Funding for the projects came from client budgets and/or from a community development grant awarded to the campus Center for Service-Learning. All projects were conducted within a project management framework based on the systems development life cycle (SDLC, also called the systems lifecycle) [25].

The student teams managed and executed the projects in cooperation with client representatives and with instructor oversight. Students worked directly on site interviewing client staff, interacting with customers of the client, and testing and deploying the systems they developed. They met periodically with the instructor throughout the semester. They made formal project management and design walkthrough presentations to the class and to client representatives. They also reported the final completion of the project at semester's end. A formal letter of acceptance from the client indicating satisfactory system completion was required for a grade in the course. Table 1 shows the major project components in order:

Table 1. Approximate Project Timeline

\begin{tabular}{|c|c|c|}
\hline Date & Activity & Deliverable \\
\hline Week 1 & Course/Project Introduction & Student Buy-In \\
\hline Week 1 & Team Formation & Meeting with Instructor \\
\hline Week 1 & Client Assignment & Meeting with Instructor \\
\hline Week $2-4$ & $\begin{array}{l}\text { MIS Instruction and Review in } \\
\text { Strategic Planning, Project } \\
\text { Management, System } \\
\text { Development, Ethics }\end{array}$ & Class attendance and discussion \\
\hline Week $2-4$ & Project Identification & Meeting with Client \\
\hline Week 6 & Project Plan Approval & Meeting with Instructor \\
\hline Week 8 & Project Design Approval & Meeting with Client \& Instructor \\
\hline Week 9 & Project Plan Presentation & $\begin{array}{l}\text { Interactive PowerPoint Presentation to Class, } \\
\text { Client, and Instructor on Project } \\
\text { Definition/Scope, Project Staffing Plan, } \\
\text { Project Budget Plan, Project Schedule }\end{array}$ \\
\hline Week 9 & Project Design Presentation & $\begin{array}{l}\text { Interactive PowerPoint Presentation to Class, } \\
\text { Client, and Instructor on Existing System } \\
\text { Analysis, New System Design, Cost-Benefit } \\
\text { Analysis, Coding Plan, Testing Plan, }\end{array}$ \\
\hline
\end{tabular}


$\begin{array}{ll}\text { Week 10 - 15 } & \text { Project Execution } \\ \text { Week 15 } & \text { Project Completion Debriefing } \\ \text { Week 15 } & \text { Final Project Approval }\end{array}$
Deployment Plan, Training Plan, Maintenance Plan

Project Implemented for Client

Project Demonstration to Class and Instructor

Project Approval Letter from Client

Ethically significant engagement. All participants unavoidably modeled ethical (or, occasionally, unethical) behaviors in numerous ways. Phone calls and email messages were (or were not) returned in a timely manner. Meeting appointments were kept (or not). Students strove to understand user requirements even when the users were physically disabled, mentally compromised, or emotionally unstable. The importance of developing honest, reasonably accurate budgets and then adhering to them became clear. Setting reasonable product expectations and managing scope creep were significant issues in every project. Clients and students had to practice maintaining effective interpersonal communication in the face of delays, malfunctions, or misunderstandings. Students discovered that client business processes were materially affected by project progress. They also found that a maintenance plan to assure successful system functioning after semester's end was crucial—client needs did not evaporate when the course ended.

Reinforcement. In addition to the customary reinforcement of a course grade, student efforts were recognized by campus and community leaders. The United Way hosted all participating students at its annual Gold Awards breakfast and had them stand to receive the applause of local community leaders. The campus annual report featured a multi-page article on the projects and color photos of the students working with their clients. Students were presented with tokens of esteem from the campus Center for Service-Learning in front of the annual Information Technology Seminar.

The clients and the people the clients serve also reinforced the students' ethical behavior. Client staff were generous and sincere in their praise of student skills. They were gentle and quick with forgiveness of student mistakes, and they were vocal and frequent in expressing their gratitude for student contributions.

\section{RESULTS/DISCUSSION}

The effects of the experience on the students appear to have been ethically quite salutary. Table 2 is a general qualitative description of ethics-related statements by the students at three points in the semester:

Table 2. Qualitative Temporal Analysis of Ethics-Related Student Statements

\begin{tabular}{lll} 
Date & Activity & Remarks \\
\hline Week 4 & MIS Ethics Review & Quantity: Few \\
& & Insight: Shallow, bored \\
& & Altruism: Low \\
& Topics: Defense of file trading \\
\hline Week 9 & Project Design Presentation & Quantity: Many \\
& & Insight: Moderate \\
& & Altruism: Moderate \\
& & Topics: Varied, project-related \\
\hline Week 15 & Project Completion Debriefing & Quantity: Many \\
& & Insight: Deep \\
& & Altruism: High \\
& & Topics: Varied, client-related \\
\hline
\end{tabular}




\section{The Good News}

At the end of the project, every student commented on the obvious impact of the projects on the local community. Every student reported pleasant surprise at the expressions of gratitude from clients and other community and campus members. Many students commented on a new sense of involvement and connectedness; here are a few examples:

"I never knew how much I was needed."

"I didn't know how much I knew."

"I hadn't realized how different it is for a handicapped person to use a computer."

"They really depended on us to do what we said we'd do."

"This has been my best experience in college."

About half the students reported ethically significant experiences that surprised even the instructor. For example, more than one project team had to educate clients on the illegality of software piracy and the risks of participation in peer-to-peer file trading networks. Students found themselves explaining purchase conditions and license agreements to their clients. One team gave their client a USB flash drive and trained them in its use midway through the project when it was discovered that the entire customer database, without which the organization could not function, had never been backed up. Several students developed such a committed relationship with their client that they established gratis after-project maintenance agreements that extended weeks or months past the end of the semester. Most students spoke warmly of lasting friendships they had developed.

\section{The Bad News}

Not all the news was good. One team did not complete their project until several weeks after the end of the semester, and even then their primary motivation seemed to be their course grade rather than the commitments they had made to their client. Moreover, the product they created, while workable, was of marginal quality. The client was justifiably frustrated with the sub-par performance but thankfully did still conclude, once the project was complete, that the organization was further ahead than before.

While we hope not to repeat an experience like this, we still believe it was good ethics education for the students. They and the instructor discussed several times the risks of exaggerating one's technical prowess and minimizing the importance of meetings, deadlines, requirements analysis, and project management. They did not initially accept the instructor's counsel sufficiently to change their relationship with their client, and so they ended up receiving more pointed feedback later. In their final meeting with the instructor, two of the three students did give some indication that they had begun to appreciate the need for more honesty, humility, responsiveness, attention to administrative detail, careful communication, and other ethical behaviors in their MIS work.

\section{CONCLUSIONS}

We finished the experience with the strong impression that this is a much-needed component of MIS ethics education. Thus, we are now in our fourth semester, and things are going excellently. Students continue to experience firsthand the positive influence they can have when conducting themselves appropriately, and most do; on the other hand, they also experience firsthand the disappointment associated with unethical behavior, which has so far been blessedly rare.

Laziness and naïveté rather than malice or sociopathy seem to be emerging as the primary motivators of the unethical behavior we have encountered. We choose to regard this as relatively good news both because things are not as bad as they might be and because we see the project experience as an ideal treatment for laziness and naïveté, whereas it would be a decidedly inappropriate context for addressing malice or sociopathy. 
We are left with a number of questions about our experience that we hope to investigate further in the future. However, we conclude here with the one on which we most desire help from our colleagues: Given that MIS student behavior conformed in large measure to accepted ethics norms throughout the project, should we conclude that, contrary to much of the literature, ethics are really very easy to teach? Or should we look for a variable other than the class experiences to account for the result? For instance, might students' ethics-related behavior reflect their perceptions of expectations - that is, if the university communicated the clear expectation of ethical behavior on campus, might the students respond by behaving as ethically on campus as they did off campus?

\section{REFERENCES}

1. ABET (2004). Criteria for Accrediting Computing Programs. Baltimore: Computing Accreditation Commission of the Accreditation Board for Engineering and Technology. Retrieved May 12, 2005, from http://www.abet.org/Linked\%20DocumentsUPDATE/Criteria\%20and\%20PP/05-06-CAC\%20Criteria.pdf.

2. Association for Computing Machinery (1992). ACM Code of Ethics and Professional Conduct. Retrieved May 14, 2004, from http://www.acm.org/constitution/code.html.

3. Association for Computing Machinery (1999). Software Engineering Code of Ethics and Professional Practice. Retrieved May 14, 2004, from http://www.acm.org/constitution/code .html.

4. Association of Information Technology Professionals (2002). Code of Ethics. Retrieved May 14, 2004, from http://www.aitp.org/organization/about/ethics/ethics.jsp.

5. Bandura, A. (1985). Social Foundations of Thought and Action. Upper Saddle River, NJ: Pearson Prentice Hall.

6. Brinkmann, J. \& Sims, R. R. (May 2001). Stakeholder-sensitive business ethics teaching. Teaching Business Ethics, 5(2), 171-193.

7. Carroll, A. B. (January/February 2005). An ethical education. BizEd, 26-40.

8. Caruana A., Ramaseshan, B. \& Ewing, M.T. (January 2000). The effect of anomie on academic dishonesty among university students. The International Journal of Educational Management, 14(1), 2-3.

9. Corporate Ethics (2005). Retrieved May 12, 2005, from http://www.washingtonpost.com/wp-dyn/business/specials/corporateethics/.

10. Croteau, D. \& Hoynes, W. (2002). Media/Society: Industries, Images and Audiences $\left(3^{\text {rd }}\right.$ ed.). Thousand Oaks, CA: Pine Forge Press.

11. Dewey, J. (1916). Democracy and Education. New York: The Macmillan Company. Copyright renewed 1944 by Macmillan Company, 1994 by ILT Digital.

12. Goldiamond, I. (2002). Toward a constructional approach to social problems: Ethical and constitutional issues raised by applied behavior analysis. Behavior and Social Issues, 11, 108-197.

13. Hill, A. L. (April 2004). Ethics education: Recommendations for an evolving discipline. Counseling and Values, 48(3), 183-203.

14. Hilton, T. Oh, S. \& Al-Lawati, H. (2004). Information systems ethics in Oman, South Korea, and the USA. Information Systems Education Journal. Chicago: EDSIG, the Education Special Interest Group of AITP, the Association of Information Technology Professionals. Retrieved May 12, 2005 from http://isedj.org/isecon/2004/3253/ISECON.2004.Hilton.pdf.

15. Hilton, T. S. (1999). A model for Internet-enhanced education systems derived from history and experiment. Journal of Computer Information Systems, 39(3), 6-17.

16. Hinduja, S. (March 2003). Trends and patterns among online software pirates. Ethics and Information Technology, 5(1), 49-61.

17. Husted, B. W. (July 1999). A critique of the empirical methods of integrative social contracts theory. Journal of Business Ethics. 20(3), 227-236. 
18. Hutchison, L. L. (August 2002). Teaching ethics across the public relations curriculum. Public Relations Review. 28(3), 301.

19. IEEE Code of Ethics (1990). Retrieved May 12, 2005, from http://www.ieee.org/portal/ index.jsp?pageID=corp_level1\&path=about/whatis\&file=code.xml\&xsl=generic.xsl.

20. Kant, I. (1959). The Foundations of the Metaphysics of Morals (L. W. Beck, Trans.). New York: Liberal Arts Press. (Original work published 1785).

21. Kaptein, M. \& Wempe, J. (June 1998). Twelve Gordian knots when developing an organizational code of ethics. Journal of Business Ethics. 17(8), 853-870.

22. Keans, C. \& Kearns, C. (2004). Value-Centered Ethics. Amherst, MA: HRD Press.

23. Ladd, J. (1989). Computers and Moral Responsibility: A Framework for Ethical Analysis. In C. Gould (Ed.), The Information Web: Ethical and Social Implications of Computer Networking (pp. 207-227). Boulder, CO: Westview Press.

24. Lampe, M. (July 1997). Increasing effectiveness in teaching ethics to undergraduate business students. Teaching Business Ethics, 1(1), 3-19.

25. Laudon, K. C. \& Laudon, J. P. (2004). Redesigning the Organization with Information Systems. In Management Information systems: Managing the Digital Firm ( $8^{\text {th }}$ ed.). Upper Saddle River, NJ: Pearson Prentice Hall.

26. Loeb, S. E. \& Ostas, D. T. (August 2000). The team teaching of business ethics in a weekly semester long format. Teaching Business Ethics. 4(3), 225-238.

27. MacIntyre, A. C. (1999). Dependent Rational Animals: Why Human Beings Need the Virtues. Chicago: Open Court.

28. Marino, G. (February 20, 2004). Before teaching ethics, stop kidding yourself. Chronicle of Higher Education. 50(24), B5.

29. McCarthy, E. (April 21, 2005). BearingPoint cites SEC inquiry, warns investors. Washington Post, E01.

30. Mill, J. S. (1863). Utilitarianism. Raleigh, N.C.: Alex Catalogue.

31. Morrell, K. (September 2004). Socratic dialogue as a tool for teaching business ethics. Journal of Business Ethics. 53(4), 383.

32. New reporting and compliance rules challenge systems at most large U.S. companies, PricewaterhouseCoopers finds. (2004). Management Barometer. Retrieved May 12, 2005 , from http://www.barometersurveys.com/production/barsurv.nsf/1cf3264823a1149c85256b84 006d2696/2d661c6b82d4391185256ee0006eed74?OpenDocument.

33. Oz, E. (December1992). Ethical standards for information systems professionals: A case for a unified code. MIS Quarterly. 16(4), 423- 433.

34. Peer-to-peer piracy on university campuses: Hearing before the Subcommittee on Courts, the Internet, and Intellectual Property of the Committee on the Judiciary, House of Representatives, 108a Cong., 1 (2003).

35. Peters, E. (1997). Torture. Philadelphia: University of Pennsylvania Press.

36. Phillips, S. M., Blood, M., Bosland, N., Burke, L., Conrad, C. F., Fernandes, J., et al. (2004). Ethics Education in Business Schools: Report of the Ethics Education Task Force to AACSB International's Board of Directors. St. Louis: AACSB International.

37. Pino, N. W. \& Smith, W. L. (December 2003). College students and academic dishonesty. College Student Journal.

38. Rawls, J. (1971). A Theory of Justice. Boston: The Belknap Press of Harvard University Press.

39. Skinner, B. F. (1953). Science and Human Behavior. New York: Macmillan.

40. Vardi, Y. \& Weitz, E. (2004). Misbehavior in Organizations: Theory, Research, and Management. Mahwah, NJ: L. Erlbaum.

41. Weizenbaum, J. (1976). Computer Power and Human Reason, San Francisco: W. H. Freeman and Company. 